\title{
ASSOCIATION ANALYSIS BETWEEN A VNTR INTRON 8 POLYMORPHISM OF THE DOPAMINE TRANSPORTER GENE (SLC6A3) AND OBSESSIVE- COMPULSIVE DISORDER IN A BRAZILIAN SAMPLE
}

\author{
Karen Miguita', Quirino Cordeiro', Jacqueline Siqueira-Roberto', \\ Roseli Gedanke Shavitt², José Carlos Ramos Castillo', Ana Regina Castillo', \\ Euripedes Constantino Miguel ${ }^{3}$, Homero Vallada 4
}

\begin{abstract}
Family, twin and segregation analysis have provided evidences that genetic factors are implicated in the susceptibility for obsessive-compulsive disorder (OCD). Several lines of research suggest that the dopaminergic system may be involved in the pathophysiology of OCD. Thus, the aim of the present study was to investigate a possible association between a polymorphism located in intron 8 of the dopamine transporter gene ( $\mathrm{SLC}_{\mathrm{C}} \mathrm{A} 3$ ) and $\mathrm{OCD}$ in a Brazilian sample composed by 208 patients and 865 healthy controls. No statistically differences were observed in allelic and genotype distributions between cases and controls. No association was also observed when the sample was divided according to specific phenotypic features such as gender, presence of tic disorders co-morbidity and age at onset of obsessive-compulsive symptoms (OCS). Our results suggest that the intron 8 VNTR of the SLC6A3 investigated in this study is not related to the susceptibility for OCD in our Brazilian sample.
\end{abstract}

KEY WORDS: dopamine, obsessive-compulsive disorder, genetic association, DAT1, allele, genotype.

\begin{abstract}
Análise de associação entre um polimorfismo VNTR no intron 8 do gene do transportador de dopamina (SLC6A3) e transtorno obsessivo-compulsivo em uma amostra brasileira

RESUMO - Estudos de família, gêmeos e de segregação têm demonstrado que fatores genéticos estão envolvidos na susceptibilidade para o desenvolvimento do transtorno obsessivo-compulsivo (TOC). Várias linhas de pesquisa sugerem que o sistema dopaminérgico possa estar envolvido na fisiopatologia do TOC. Assim, o objetivo do presente estudo foi investigar uma possível associação entre o polimorfismo localizado no intron 8 do gene do transportador da dopamina (SLC6A3) e o TOC em uma amostra brasileira composta por 208 pacientes e 865 controles sadios. Nenhuma diferença estatisticamente significante foi observada nas distribuições alélicas e genotípicas entre os grupos de pacientes e controles. Nenhuma associação também foi observada quando as amostras foram divididas de acordo com características fenotípicas específicas, tais como gênero, presença de co-morbidade com tiques e idade de início dos sintomas obsessivocompulsivo (SOC). Nossos resultados sugerem que o VNTR do intron 8 investigado neste estudo não está relacionado com o TOC na nossa amostra brasileira.
\end{abstract}

PALAVRAS-CHAVE: dopamina, associação genética, DAT1, alelo, genótipo.

Obsessive-compulsive disorder (OCD) is a common and heterogeneous neuropsychiatric disorder characterized by obsessions (intrusive and recurrent thoughts, images or impulses) and compulsions (repetitive behaviors or mental acts usually performed to relive obsessions). OCD prevalence ranges from 2 to $3 \%$ in general population and it has approximately equal sex distributions, but men tend to have an earlier age at onset of obsessive-compulsive symptoms (OCS) comparing to women ${ }^{1,2}$. Although the etiol-

\footnotetext{
Department and Institute of Psychiatry Progene LIM-23, University of São Paulo Medical School, São Paulo SP, Brazil (HC-FMUSP): 'Pesquisador do Programa de Genética e Farmacogenética (PROGENE) do Instituto de Psiquiatria do HC-FMUSP, São Paulo SP, Brazil; ${ }^{2}$ Pesquisadora do Projeto do Espectro do Transtorno Obsessivo-Compulsivo (PROTOC) do Instituto de Psiquiatria do HC-FMUSP; ${ }^{3}$ Professor Associado do Departamento de Psiquiatria da FMUSP, Coordenador do PROTOC do Instituto de Psiquiatria do HC-FMUSP; 4Professor Associado do Departamento de Psiquiatria da FMUSP, Coordenador do PROGENE do Instituto de Psiquiatria do HC-FMUSP. This study was supported by grants from Fundação de Amparo à Pesquisa do Estado de São Paulo (FAPESP) to Dr. Shavitt (grant no. 99/01548-0), Dr Vallada and Dr. Miguel (99/12205-7/; 2005/55628-8), and from CAPES. Additional support was provided by a Conselho Nacional de Desenvolvimento Científico e Tecnológico (CNPQ, Brazilian Council for Scientific and Technological Development) grant to Miguel (grant \#521369/96-7).
}

Received 8 May 2007. Accepted 18 August 2007.

Dra. Karen Miguita - Rua Tenente Miguel Delia 244 - o8021-ogo São Paulo SP - Brasil. E-mail: kmig@bol.com.br 
ogy of the disorder remains unknown, twin, family and segregation analysis have provided great evidence that OCD has a strong genetic component ${ }^{3,4}$. Twin studies have found a concordance of $63-87 \%$ among monozygotic twin pairs and $22-47 \%$ among dizygotic twin pairs ${ }^{5}$ and family studies have shown an increased prevalence of OCD among first-degree relatives of patients with $O C D$, suggesting that the risk for the development of the disorder is 3-12 times greater when compared to the prevalence among first-degree relatives of control subjects ${ }^{6-8}$. Segregation analysis have suggested evidence of a possible major dominant or co-dominant model of transmission for OCD, but these studies are not conclusive yet ${ }^{8}$.

Several lines of evidence suggest that the dopaminergic system may be involved in the pathophysiology of OCD. For instance, neuroimaging studies have revealed abnormalities in brain regions densely endowed with dopaminergic terminals, such as the basal ganglia. In some studies, Dopamine D2 receptor binding potential is decreased ${ }^{9}$ and dopamine transporter binding potential is up-regulated in the basal ganglia of OCD patients which is compatible with the hypothesis of an enhanced dopaminergic activity ${ }^{10}$. In addition, dopamine releasing agents and uptake inhibitors, such as metilfenidate, cocaine, bromocriptine, and bupoprion, exacerbate obsessive-compulsive symptoms (OCS) in OCD patients". Finally, the addition of dopaminergic antagonists has shown efficacy on treatment of refractory OCD patients, especially those with tic disorders (i.e., chronic motor or vocal tics or Tourette syndrome (TS) co-morbidity ${ }^{12}$. Following the hypothesis of the role of dopaminergic system in OCD, numerous studies have been investigating genetic polymorphisms related to this neurotransmitter. The most commonly dopamine transporter gene (SLC6A3) polymorphism studied in OCD is a $40-b p$ variable-number tandem repeat (VNTR) located in the 3 'UTR region which has repeated copies ranging from 3 to 11, however the results have failed to associate this VNTR polymorphism with OCD ${ }^{13-15}$.

In this way, in the present study we tested a possible association of another SLC6A3 polymorphism, a zobp VNTR located in intron 8 of this gene, with $O C D$, which was not previously investigated in patients with this disorder.

\section{METHOD}

Sample - Two hundred and eight (male $=131-63 \%$; female $=77-37 \%$ ) Brazilian OCD outpatients were recruited at the Institute of Psychiatry, Hospital das Clínicas, University of São Paulo Medical School. Diagnosis of OCD was established according to DSM-IV criteria, using the Structured Clinical Interview for DSM-IV (SCID) ${ }^{16}$, supplemented with additional modules based on DSM-IV criteria for tic disorders (i.e., chronic motor or vocal tics or TS) (available upon request). A total of 865 ( male $=589-68.1 \%$; female $=276-31.9 \%$ ) healthy control subjects were selected from unrelated subjects admitted to the Blood Donation Center of the Fundação PróSangue of the University of São Paulo Medical School.

We defined "age at onset of OCS" in the present study as the age that the patient, or a family member, remembered as the beginning of the OCS. There is no agreement in the literature about the age threshold for defining "early onset" in OCD patients ${ }^{17}$. We selected a threshold of age 10 for the early onset group and age 17 for the late onset group. These thresholds are consistent with results form OCD genetic family studies ${ }^{3,8}$, suggesting a higher morbidity risk to first-degree family members of early-onset probands for OCD ( $\leq 10$ years) ${ }^{3}$, compared to the first degree family members of probands with later onsets ${ }^{8}$.

All patients and control subjects provided written informed consent for taking blood samples. Ethical approval for the study was obtained from the Ethics Committee at the Hospital das Clínicas, University of São Paulo Medical School (CAPPesq).

DNA extraction - Blood samples $(10 \mathrm{~mL})$ were collected from all participants and DNA was extracted from leukocytes using the salting out protocol ${ }^{18}$.

Genotyping - Polymerase chain reaction (PCR) was carried out using: $20 \mathrm{ng}$ of genomic DNA, $25 \mathrm{mM} \mathrm{MgCl}_{2}, 10 \mathrm{pmol}$ of each specific primer (F: 5 '-GCTTGGGGAAGGAAGGG-3' AND R: 5 '-TGTGTGCGTGCATGTGG-3'), $200 \mu \mathrm{M}$ dNTP, 5 U/ $\mu \mathrm{L}$ Taq DNA Polymerase and $1 x$ buffer in $10 \mu \mathrm{L}$ reactions. The PCR conditions were: $95^{\circ} \mathrm{C}$ for $5 \mathrm{~min}$. followed by 40 cycles $\left(95^{\circ} \mathrm{C}\right.$ for $45 \mathrm{~s}, 63^{\circ} \mathrm{C}$ for $45 \mathrm{~s}$ and $72^{\circ} \mathrm{C}$ for $45 \mathrm{~s}$ ) and a final extension at $72^{\circ} \mathrm{C}$ for $6 \mathrm{~min}$. PCR products were separated on $2 \%$ agarose gels stained with ethidium bromide and viewed under UV light. The primers used were previously described in Guindalini et al. ${ }^{19}$.

To avoid errors, genotyping was read by two independently trained research technicians. When a disagreement arose the genotyping was repeated.

Statistical analysis - Allelic and genotypic distributions of the SLC6A3 polymorphism were compared between 208 patients and 865 controls. We also performed analysis for gender, presence of tic disorders co-morbidity and for age at onset of OCS. Statistical Clump v.1.9 software ${ }^{20}$ was used for the analysis. This program generates $p$ values based on Monte Carlo simulations, in which repeated simulations are performed in order to achieve significant levels with more accuracy. This program also produces another $p$ value by collapsing columns with small expected values into one group to establish a new two-to-two table, maximizing the chi-squared value and producing more conservative results. A test for deviations from the Hardy-Weinberg equilibrium was performed using the HWE program ${ }^{21}$. For all statistic tests the level of significance adopted was $\alpha<0.05$ or $5 \%$. 
Table 1. Distribution of the genotypes and alleles of the VNTR intron 8 polymorphism of the $\mathrm{SLC6A3}$ between patients and controls.

\begin{tabular}{cccccc}
\hline \multicolumn{1}{c}{ Patients } & Controls & $\chi^{2}$ & df. & $p$ \\
\hline Genotypes & & & & & \\
$1-3$ & - & $5(0.6 \%)$ & & & \\
$1-2$ & $14(6.7 \%)$ & $77(8.9 \%)$ & & & \\
$2-3$ & $99(47.6 \%)$ & $409(47.3 \%)$ & & & 0.37 \\
$2-5$ & - & $3(0.3 \%)$ & 6.43 & 6 & \\
$3-3$ & $95(45.7 \%)$ & $359(41.5 \%)$ & & & \\
$3-4$ & - & $1(0.1 \%)$ & & \\
$3-5$ & - & $11(0.3 \%)$ & & \\
Total & $208(100 \%)$ & $865(100 \%)$ & & \\
Alleles & $14(3.4 \%)$ & $82(4.7 \%)$ & & \\
1 & $113(27.2 \%)$ & $489(28.3 \%)$ & & \\
2 & $289(69.4 \%)$ & $1144(66.1 \%)$ & 5.73 & 4 & \\
3 & - & $1(0.1 \%)$ & & & \\
4 & - & $14(0.8 \%)$ & & & \\
5 & $416(100 \%)$ & $1730(100 \%)$ & & \\
Total & & & & \\
\hline
\end{tabular}

Table 2. Distribution of the genotypes and alleles of the VNTR intron 8 polymorphism of the SLC6A3 by gender.

\begin{tabular}{|c|c|c|c|c|c|}
\hline & Patients & Controls & $\chi^{2}$ & df. & $\mathrm{p}$ \\
\hline \multicolumn{6}{|l|}{ Males } \\
\hline \multicolumn{6}{|l|}{ Genotypes } \\
\hline $1-3$ & - & $5(0.8 \%)$ & & & \\
\hline $1-2$ & $10(7.7 \%)$ & $49(8.3 \%)$ & & & \\
\hline $2-3$ & $64(48.8 \%)$ & $288(48.9 \%)$ & & & \\
\hline $2-5$ & - & $3(0.5 \%)$ & 3.42 & 6 & 0.75 \\
\hline $3-3$ & $57(43.5 \%)$ & $238(40.4 \%)$ & & & \\
\hline $3-4$ & - & $1(0.2 \%)$ & & & \\
\hline 3- 5 & - & $5(0.8 \%)$ & & & \\
\hline Total & $131(100 \%)$ & $589(100 \%)$ & & & \\
\hline \multicolumn{6}{|l|}{ Alleles } \\
\hline 1 & $10(3.8 \%)$ & $54(4.6 \%)$ & & & \\
\hline 2 & $74(28.3 \%)$ & $340(28,8 \%)$ & & & \\
\hline 3 & $178(67.9 \%)$ & $775(65.8 \%)$ & 2.46 & 4 & 0.65 \\
\hline 4 & - & $1(0.1 \%)$ & & & \\
\hline 5 & - & $8(0.7 \%)$ & & & \\
\hline Total & $262(100 \%)$ & $1178(7.7 \%)$ & & & \\
\hline \multicolumn{6}{|l|}{ Females } \\
\hline \multicolumn{6}{|l|}{ Genotypes } \\
\hline $2-2$ & $4(5.2 \%)$ & $28(10.2 \%)$ & & & \\
\hline $2-3$ & $35(45.4 \%)$ & $121(43.8 \%)$ & 3.74 & 3 & 0.29 \\
\hline $3-3$ & $38(49.4 \%)$ & $121(43.8 \%)$ & & & \\
\hline $3-5$ & - & $6(2.2 \%)$ & & & \\
\hline Total & $77(100 \%)$ & $276(100 \%)$ & & & \\
\hline \multicolumn{6}{|l|}{ Alleles } \\
\hline 2 & $43(27.9 \%)$ & $177(32.1 \%)$ & & & \\
\hline 3 & $111(72.1 \%)$ & $369(66.8 \%)$ & 2.82 & 2 & 0.24 \\
\hline 5 & - & $6(1.1 \%)$ & & & \\
\hline Total & $154(100 \%)$ & $552(100 \%)$ & & & \\
\hline
\end{tabular}




\section{RESULTS}

No statistical significant differences were observed for the analysis performed in our sample involving the allelic and genotypic distribution between patients and controls (Table 1). Likewise, no significant results emerged when these groups were divided by gender (Table 2).

Presence of tic disorders co-morbidity was investigated in $166(79.8 \%)$ patients of the total sample. Of those $84(50.6 \%)$ has presented this co-morbidity. There was no statistical significant difference involving the allelic and genotypic distribution between
OCD patients with tic disorders and patients with no tic disorders (Table 3). Analysis for age at onset of OCS was performed comparing patients with early onset (age 10 or earlier) and late onset (age 17 or later). In our sample, we had information of age at onset of OCS from $160(76.9 \%)$ patients of the total: 94 $(58.8 \%)$ had an early onset, $29(18.1 \%)$ a late onset and $37(23.1 \%)$ an intermediate onset of their OCS (age from 11 to 16). We compared patients with early onset (EO) to those with late onset (LO). Again, no association was observed when analysis were performed for these two groups of patients (EO x LO) (Table 4).

Table 3. Distribution for genotypes and alleles of the VNTR intron 8 polymorphism of the $\mathrm{SLC6A_{3 }}$ by the presence of tic disorders (chronic motor or vocal tics or TS) co-morbidity.

\begin{tabular}{cccccc}
\hline & \multicolumn{2}{c}{ Tic disorders } & $\chi^{2}$ & df. & $p$ \\
\cline { 2 - 3 } Genotypes & Presence & Absence & & & \\
$2-2$ & $4(4.8 \%)$ & $10(12.2 \%)$ & & & \\
$2-3$ & $44(52.4 \%)$ & $34(41.5 \%)$ & 3.88 & 2 & 0.14 \\
$3-3$ & $36(42.8 \%)$ & $38(46.3 \%)$ & & & \\
Total & $84(100 \%)$ & $82(100 \%)$ & & & \\
Alleles & & & & & \\
2 & $54(32.9 \%)$ & $52(31.0 \%)$ & & & 0.70 \\
3 & $110(67.1 \%)$ & $116(69.0 \%)$ & 0.15 & 1 & \\
Total & $164(100 \%)$ & $168(100 \%)$ & & & \\
\hline
\end{tabular}

Table 4. Distribution for genotypes and alleles of the VNTR intron 8 polymorphism of the $S L C 6 A_{3}$ by age at onset of OCS.

\begin{tabular}{|c|c|c|c|c|c|}
\hline & \multicolumn{2}{|c|}{ Age at onset of OCS* } & \multirow[t]{2}{*}{$\chi^{2}$} & \multirow[t]{2}{*}{ df. } & \multirow[t]{2}{*}{$\mathrm{p}$} \\
\hline & Early & Late & & & \\
\hline \multicolumn{6}{|l|}{ Genotypes } \\
\hline $2-2$ & $8(8.6 \%)$ & $3(10.4 \%)$ & & & \\
\hline $2-3$ & $43(45.7 \%)$ & $9(31.0 \%)$ & 1.97 & 2 & 0.37 \\
\hline $\begin{array}{l}\text { 3-3 } \\
\text { Total }\end{array}$ & $\begin{array}{l}43(45.7 \%) \\
94(100 \%)\end{array}$ & $\begin{array}{l}17(58.6 \%) \\
29(100 \%)\end{array}$ & & & \\
\hline \multicolumn{6}{|l|}{ Alleles } \\
\hline 2 & $59(31.4 \%)$ & $15(25.9 \%)$ & & & \\
\hline 3 & $129(68.6 \%)$ & $43(74.1 \%)$ & 0.64 & 1 & 0.42 \\
\hline Total & $188(100 \%)$ & $58(100 \%)$ & & & \\
\hline
\end{tabular}

Table 5. Distribution for genotypes and alleles of the VNTR intron 8 polymorphism of the SLC6A3 for all analysis using collapsing $p$ values.

\begin{tabular}{lcccccccc}
\hline Analysis & \multicolumn{3}{c}{ Genotypes } & & \multicolumn{3}{c}{ Alleles } \\
\cline { 2 - 4 } & $\chi^{2}$ & $\mathrm{df}$. & $\mathrm{p}$ & & $\chi^{2}$ & $\mathrm{df}$. & $\mathrm{p}$ \\
\hline Patients and controls & 3.95 & 2 & 0.13 & & 3.96 & 2 & 0.14 \\
Male & 1.24 & 2 & 0.53 & & 0.17 & 2 & 0.56 \\
Female & 3.27 & 2 & 0.19 & & 1.51 & 1 & 0.21 \\
Tic disorders & 3.88 & 2 & 0.14 & & 0.14 & 1 & 0.66 \\
Age at onset of OCS* & 1.97 & 2 & 0.37 & & 1.47 & & 0.22 \\
\hline
\end{tabular}

*OCS, obsessive-compulsive symptoms. 
As no association was observed when the $\mathrm{p}$ values were generated from normal $\chi^{2}$ test, we considered to verify if collapsed $p$ value could show any association. However no statistical significant differences were observed. Collapsed $p$ values for all analysis are in Table 5 .

\section{DISCUSSION}

In order to investigate the hypothesis of the involvement of dopaminergic system in the pathophysiology of OCD, many studies have been conducted with genetic polymorphisms of this system, including the 40-bp VNTR and other polymorphisms related to dopaminergic system such as DRD2, DRD3 and DRD4 ${ }^{22,23}$.

In the present investigation we have tested the association of a VNTR SLC6 33 intron 8 polymorphism and OCD in a sample of 208 OCD patients (131 males and 77 females) and 865 controls ( 589 males and 276 females). This polymorphism was studied in cocaine abuse and hyperactivity disorder (ADHD) patients showing a positive association with these disorders ${ }^{19,24}$. However, as far as we know, this is the first association study analyzing this polymorphism in an OCD sample.

According to our analysis, no statistically significant differences were observed in the distribution of allelic and genotypic frequencies between the groups of patients and controls. Taking in consideration the data suggesting that OCD is a heterogeneous disorders ${ }^{25}$ we have also repeated our analyses dividing our sample according the current most important variables in the definition of OCD subtypes ${ }^{26}$. Therefore, patients and controls were investigated by gender, as some studies suggest differences in clinical manifestation of OCD according to the gender of the patients ${ }^{27,28}$. Likewise, the samples were also studied in order to verify if the investigated polymorphism could be a risk factor for tic disorders (i.e., chronic motor or vocal tics or TS) co-morbidity with OCD, since the tic-like OCD is one of the most studied OCD subgroup, exhibiting specific phenotypic features ${ }^{29}$ and particular genetic loading when compared with patients who do not present these symptoms ${ }^{25,26}$. Finally, we compared the distribution of the frequency of this VNTR polymorphism between OCD patients with early versus late onset of the disorder because patients with early age at onset of OCS have more family history of OCD which suggests a major contribution of genetic factors in the development of the disorder ${ }^{30}$. However we have not found any significant association when the analysis was conducted using these phenotypic variables described above.
A possible limitation of the present study may be related to population stratification, especially because the Brazilian population is not ethnically homogeneous, so the power to detect association may be reduced. Nevertheless, the fact that our samples are in Hardy-Weinberg equilibrium indicates that population stratification problems may not represent an important confounding factor in our study ${ }^{31}$. Moreover, ethnic matching conducted using genetic markers was performed in part of our sample in a case-control study with cocaine dependence and the results showed that despite the ethnic admixture in Brazil the ethnic stratification was not a bias in that case ${ }^{32}$.

In conclusion, the results of this study do not provide evidence of association between OCD and the VNTR intron 8 polymorphism of the dopamine transporter gene ( $\left.\mathrm{SLC}_{6} \mathrm{~A}_{3}\right)$ in the studied sample.

\section{REFERENCES}

1. Rasmussen SA, Eisen JL. Epidemiology of OCD. J Clin Psychiatry. 1990;51:10-13 discussion 14.

2. Torres AR, Lima MC. Epidemiology of obsessive-compulsive disorder: a review. Rev Bras Psiquiatr 2005; 27:237-242.

3. Pauls DL, Alsobrook JP 2nd, Goodman W, Rasmussen S, Leckman JF. A family study of obsessive-compulsive disorder. Am J Psychiatry 1995;152:76-84.

4. Hounie AG, Brotto SA, Diniz J, Chacon PJ, Miguel EC. Transtorno obsessivo-compulsivo: possíveis subgrupos. Rev Bras Psiquiatr 2001;23(2): 13-16.

5. Rasmussen SA, Tsuang MT. Clinical characteristics and family history in DSM-III obsessive compulsive disorder. Am J Psychiatry 1986;143: 317-322.

6. Lenane MC, Swedo SE, Leonard H, Pauls DL, Sceery W, Rapoport JL. Psychiatric disorders in first degree relatives of children and adolescents with obsessive-compulsive disorder. J Am Acad Child Adolesc Psychiatry 1990;29:407-412.

7. Gonzalez $\mathrm{CH}$. Aspectos genéticos do transtorno obsesivo-compulsivo. Rev Bras Psiquiatr 2001;23(2):38-41.

8. Nestadt G, Samuels J, Riddle M, et al. A family study of obsessive-compulsive disorder. Arch Gen Psychiatry 2000;57:358-363.

9. Denys D, van der Wee N, Janssen J, De Geus F, Westenberg HG. Low level of dopaminergic D2 receptor binding in obsessive-compulsive disorder. Biol Psychiatry 2004;55:1041-1045.

10. Van der Wee NJ, Stevens H, Hardeman JA, et al. Enhanced dopamine transporter density in psychotropic-naive patients with obsessive-compulsive disorder shown by [123I] \{beta\}-CIT SPECT. Am J Psychiatry 2004; 161:2201-2206

11. Jenike MA. Illnesses related to obsessive-compulsive disorder. In Jenike MA, Baer LB, Minichiello WE. Obsessive compulsive disorders: theory and management. 2.Ed. Chicago: Year Book Medical, 1990:38-60.

12. McDougle CJ, Epperson CN, Pelton GH, Wasylink S, Price LH. A double-blind, placebo-controlled study of risperidone addition in serotonin reuptake inhibitor-refractory obsessive-compulsive disorder. Arch Gen Psychiatry. 2000;57:794-801.

13. Billett EA, Richter MA, Sam F, et al. Investigation of dopamine system genes in obsessive-compulsive disorder. Psychiatr Gene 1998;8:163-169.

14. Frisch A, Michaelovsky E, Rockah R, et al. Association between obsessive-compulsive disorder and polymorphisms of genes encoding components of the serotonergic and dopaminergic pathways. Eur Neuropsychopharmacol 2000;10:205-209.

15. Hemmings SM, Kinnear CJ, Niehaus DJ, et al. Investigating the role of dopaminergic and serotonergic candidate genes in obsessive-compulsive disorder. Eur Neuropsychopharmacol. 2003;13(2):93-98.

16. First MB, Spitzer RL, Gibbon M, Williams JBW. Structured clinical interview for DSM-IV axis I disorders-patient edition (SCID-I/P), version 2. New York: New York State Psychiatric Institute: Biometrics Research, 1995. 
17. Rosario-Campos MC, Leckman JF, Mercadante MT, et al. Adults with earlyonset obsessive-compulsive disorder. Am J Psychiatry 2001;158:1899-1903

18. Miller SA, Dykes DD, Polesky HF. A simple salting out procedure for extracting DNA from human nucleated cells. Nucleic Acids Res 1988;16:1215.

19. Guindalini C, Howard M, Haddley K, et al. A dopamine transporter gene functional variant associated with cocaine abuse in a Brazilian sample. Proc Natl Acad Sci USA 2006;103:4552-4557.

20. Sham PC, Curtis D. Monte Carlos tests for associations between disease and alleles at highy polymorfhic loci. Ann Hum Genet 1995;59:97-105.

21. Ott J. Utility programs for analysis of genetic linkage. New York: Columbia University, 1988

22. Millet B, Chabane N, Delorme R, et al. Association between the dopamine receptor D4 (DRD4) gene and obsessive-compulsive disorder. Am J Med Genet B Neuropsychiatr Genet 2003;116:55-59.

23. Denys D, Van Nieuwerburgh F, Deforce D, Westenberg H. Association between the dopamine D2 receptor TaqI A2 allele and low activity COMT allele with obsessive-compulsive disorder in males. Eur Neuropsychopharmacol 2006;16:446-450.

24. Asherson P, Brookes K, Franke B, et al. Confirmation that a specific haplotype of the dopamine transporter gene is associated with combinedtype ADHD. Am J Psychiatry 2007;164:674-677.
25. Miguel EC, Leckman JF, Rauch S, et al. Obsessive-compulsive disorder phenotypes: implications for genetic studies. Molec Psychiatry 2005;10:258-275.

26. Mathis MA, Diniz JB, Rosario MC, et al. What is the optimal way to subdivide obsessive-compulsive disorder? CNS Spectr 2006;11:762-779.

27. Karayiorgou M, Sobin C, Blundell ML, et al. Family-based association studies support a sexually dimorphic effect of COMT and MAOA on genetic susceptibility to obsessive-compulsive disorder. Biol Psychiatry 1999:45:1178-1189.

28. Alsobrook JP 2nd, Zohar AH, Leboyer M, Chabane N, Ebstein RP, Pauls DL. Association between the COMT locus and obsessive-compulsive disorder in females but not males. Am J Med Gene. 2002;114:116-120

29. Diniz JB, Rosario-Campos MC, Hounie AG, et al. Chronics tics and Tourette syndrome in patients with obsessive-compulsive disorder. J Psych Res 2006;40:487-493.

30. Rosario-Campos MC, Leckman JF, Curi M, et al. A family study of early-onset obsessive-compulsive disorder. Am J Med Genet B Neuropsychiatr Genet 2005;12;136:92-97.

31. Weiss ST, Silverman EK, Palmer LJ. Editorial: case-control association studies in pharmacogenetics. Pharmacogenomics J 2001;1:157-158.

32. Guindalini C, O'Gara C, Laranjeira R, et al. A GSTP1 functional variant associated with cocaine dependence in a Brazilian population. Pharmacogenet Genomics 2005;15:891-893. 